\title{
Brown trout redd superimposition in relation to spawning habitat availability
}

\author{
Javier Gortázar ${ }^{1,2}$, Carlos Alonso², Diego García de Jalón ${ }^{2}$ \\ ${ }^{1}$ Ecohidráulica, S.L., Madrid, Spain \\ ${ }^{2}$ ETS Ingenieros de Montes, Universidad Politécnica de Madrid, Madrid, Spain
}

Accepted for publication December 2, 2011

Abstract -The relationship between redd superimposition and spawning habitat availability was investigated in the brown trout (Salmo trutta L.) population inhabiting the river Castril (Granada, Spain). Redd surveys were conducted in 24 river sections to estimate the rate of redd superimposition. Used and available microhabitat was evaluated to compute the suitable spawning habitat (SSH) for brown trout. After analysing the microhabitat characteristics positively selected by females, SSH was defined as an area that met all the following five requirements: water depth between 10 and $50 \mathrm{~cm}$, mean water velocity between 30 and $60 \mathrm{~cm} \mathrm{~s}^{-1}$, bottom water velocity between 15 and $60 \mathrm{~cm} \mathrm{~s}^{-1}$, substrate size between 4 and $30 \mathrm{~mm}$ and no embeddedness. Simple regression analyses showed that redd superimposition was not correlated with redd numbers, SSH or redd density. A simulation-based analysis was performed to estimate the superimposition rate if redds were randomly placed inside the SSH. This analysis revealed that the observed superimposition rate was higher than expected in 23 of 24 instances, this difference being significant $(P<0.05)$ in eight instances and right at the limit of statistical significance $(P=0.05)$ in another eight instances. Redd superimposition was high in sections with high redd density. High superimposition however was not exclusive to sections with high redd density and was found in moderate- and low-redd-density sections. This suggests that factors other than habitat availability are also responsible for redd superimposition. We argue that female preference for spawning over previously excavated redds may be the most likely explanation for high superimposition at lower densities.

Key words: brown trout; redd; redd superimposition; suitable spawning habitat (SSH)

\section{Introduction}

Redd superimposition, i.e., spawning over a redd site where another female has previously laid her eggs, is a common phenomenon in salmonids. It has been documented in streams where different species reproduce (Sorensen et al. 1995; Landergren 1999; Taniguchi et al. 2000). Superimposition also occurs among the individuals of a single salmonid population, both anadromous (Rubin \& Glimsäter 1996; Rubin et al. 2004) and stream resident (Champigneulle et al. 1988; Beard \& Carline 1991). Redd superimposition can potentially damage the previously laid eggs or fry (Hayes 1987; Rubin \& Glimsäter 1996; Taniguchi et al. 2000) and thus may be detrimental to population recruitment. However, it has been suggested as well that superimposition does not necessarily destroy the previous nests (Anderson 1983; Gortázar et al. 2007; Weeber et al. 2010).

High numbers of spawners in relation to suitable spawning habitat has previously been cited as the reason for redd superimposition (Champigneulle et al. 1988, 2003; Beard \& Carline 1991; Rubin et al. 2004). Conversely, Taggart et al. (2001) found that redd superimposition was not correlated with the number of spawners. Furthermore, Essington et al. (1998) showed that female density alone cannot explain redd superimposition and concluded that brown trout (Salmo trutta L.) and brook trout (Salvelinus fontinalis Mitchill) females prefer to spawn over redd sites 


\section{Gortázar et al.}

previously used by another female. They argued that the presence of an existing redd makes a particular site more attractive for spawning than it would otherwise be.

Our study was conducted in a limestone stream where processes of calcium carbonate precipitation can potentially make the substrate very cohesive and difficult to dig. Thus, it is plausible that the reuse of redd sites in this river would be a great advantage. The objective of this study was to determine, at the microhabitat scale, whether spawning habitat availability can explain redd superimposition or whether other factors such as female preference for reusing redd sites are responsible.

\section{Material and methods}

\section{Study area}

The study was performed in the upper reaches of the river Castril, a limestone, aquifer-fed stream, located in the province of Granada (Andalusia, south-eastern Spain). Brown trout is the only fish species inhabiting the study area, and this population is close to the southern limit of the natural distribution of the species (Elliott 1994). This is a native population, and it has no introgression of foreign trout alleles (Almodóvar 2007). This brown trout population has a protracted and belated reproductive season (Gortázar et al. 2007), which ranges from December to mid-April, with maximum spawning activity in February. For further details on the river Castril and its brown trout population, see Gortázar et al. (2007).

The river Castril is divided into three separate reaches by impassable obstacles. These reaches, listed from upstream to downstream, are as follows (Gortázar et al. 2007): (i) the headwaters, which is separated from the rest of the downstream river by a 500-m-long reach where the river becomes subterranean, owing to flow detraction, (ii) the main stem of the stream, which is connected to the 'El Portillo' reservoir and it is also separated from downstream by its dam and (iii) the reach below the reservoir, which is also isolated from the rest of the river upstream and downstream. Given this situation, we defined two different brown trout groups in this river: the populations inhabiting the reaches (i) and (iii), which are stream-resident trout and which will be called 'group A' from now on, and the population in reach (ii) where stream-dwelling trout coexist with larger-sized reservoir-migrant trout ('group B').

\section{Redd surveys}

Twenty-four sections within the river Castril were selected as they were known to be frequently used by spawning brown trout. Twenty-one sections are in the part of the river which is connected to the reservoir (group B). Only three sections were selected in the isolated reaches (group A) because spawning habitat is less abundant there and it was not possible to find more appropriate places.

During the spawning season 2004-2005, all the sections were visited every week to monitor the spawning activity by means of redd counts. At the end of the season (March and April), the sections were visited every other week. The methodology for identifying new and superimposed redds is described in detail in Gortázar et al. (2007), but here is a summary. Redds were identified by their configuration, with a pit upstream followed by a dome downstream, and by the lack of periphyton over the substrate, caused by female digging activities (Crisp \& Carling 1989; Grost et al. 1991). Excavations without an obvious dome or that were shorter than $60 \mathrm{~cm}$ in total length were not considered redds. The latter condition was based on the relationships between redd tail length, redd horizontal dimensions and fish length given by Crisp \& Carling (1989). Every time a new redd was detected, its horizontal dimensions were measured (length and width of pit, dome and entire redd), a sketch was drawn, and several photographs were taken. The redd position was marked on an aerial photograph, and its coordinates were recorded with GPS. For conservation reasons, we did not excavate any redds to check for the presence of eggs, but several of them were positively confirmed as redds by observing spawning trout over them.

Every redd that had been recorded in a previous survey was checked to determine whether it had changed owing to superimposition or remained unchanged. These checks were based on the comparison of the redd horizontal dimensions, sketch and photographs, between the previous and the current survey. If the redd had increased in size, or if the position and size of pit and dome had changed, we considered that a superimposed redd had been constructed over the pre-existing one (Gortázar et al. 2007). In this case, new measurements, photographs and a sketch were made. When it was not clear whether an individual redd had changed or not, we considered it unchanged (i.e., no superimposition had occurred). In summary, we considered a new individual redd to be any new continuous area of dug up gravels with a pit and a dome that was longer than $60 \mathrm{~cm}$. A superimposed redd was considered to be (i) any pre-existing redd that had been significantly enlarged and (ii) any pre-existing redd that showed different pit or dome horizontal dimensions.

Water clarity, river gradient and width $(c a .8 \mathrm{~m})$ enabled good visibility and working conditions during fieldwork, and the stream flow was moderate 
(ca. $1 \mathrm{~m}^{3} \mathrm{~s}^{-1}$ ) during the spawning season (Gortázar et al. 2007). All the redd surveys were performed by the same researcher, walking along the riverbed or riverbank. Frequent visual verifications were made to ensure that the substrate was not altered by the surveyor.

\section{Suitable Spawning Habitat (SSH)}

Sites used by brown trout females for spawning in the river Castril were characterised in a subsample of redds $(N=30)$ at the microhabitat scale. All the parameters previously considered to be important in redd site selection were measured: water depth, mean water column velocity, bottom water velocity, surface substrate size and substrate embeddedness (Shirvell \& Dungey 1983; Witzel \& MacCrimmon 1983; Essington et al. 1998; among others). We did not assess groundwater upwelling because, although it is an important parameter in redd site selection in several salmonid species (Curry \& Noakes 1995; Garrett et al. 1998; Baxter \& McPhail 1999; Baxter \& Hauer 2000), it is not as relevant in brown trout spawning (Witzel \& MacCrimmon 1983; Essington et al. 1998). Depth was measured with a graduated rod. Water velocities were measured with a Valeport Model 801 electromagnetic flow meter (flat sensor type): mean water column velocity at $60 \%$ of the water depth and bottom velocity at $3 \mathrm{~cm}$ over the gravel surface. The dominant surface substrate was measured in the field and classified into one of eight possible categories: silt $(<1 \mathrm{~mm})$, sand $(1-4 \mathrm{~mm})$, fine gravel $(4-10 \mathrm{~mm})$, medium gravel $(10-30 \mathrm{~mm})$, coarse gravel $(30-75 \mathrm{~mm})$, cobble $(75-$ $300 \mathrm{~mm})$, boulder $(>300 \mathrm{~mm})$ and bedrock. Following the study of Essington et al. (1998), substrate embeddedness was classified into three categories: (i) there are little or moderate fine elements, and the substrate can be easily dislodged with the hand; (ii) there are many fine elements, and the substrate can be dislodged with the hand with a moderate effort; and (iii) a big effort is needed to separate the gravel. These five variables were measured at three points on undisturbed gravel around the redd pit: at the upstream end and at both sides of the pit. An area of $c a .10 \mathrm{~cm}$ radius around each point was evaluated for substrate size and embeddedness. For each variable, the three measurements were averaged to give an estimate of the microhabitat value at the site where the redd was built (Crisp \& Carling 1989; Champigneulle et al. 2003). To describe the habitat available to spawning females, we also measured depth, mean velocity, bottom velocity, substrate size and embeddedness at 214 randomly selected points within the studied sections.

To evaluate microhabitat selection by spawning brown trout, we first performed Kolmogorov-
Smirnov two-sample tests (Zar 1999) to compare the distributions of available and used values for the variables depth, mean velocity, bottom velocity and substrate size. We then used the Strauss linear electivity index (Strauss 1979) to determine which values of these variables are positively selected by spawning females. For index calculation, values of each variable were divided into classes, using $10-\mathrm{cm}$ increments for depth and $15-\mathrm{cm} \mathrm{s}^{-1}$ increments for mean and bottom velocity. The Strauss electivity index is defined as: $L=r_{i}-p_{i}$ where $r_{i}$ and $p_{i}$ are the relative abundances (expressed as proportions) of used and available habitat, respectively, for the habitat class $i$. The $t$-statistic was used to test whether electivity indices $(L)$ were significantly greater than zero at the $99 \%$ significance level $(P<0.01)$. The classes in which $L$ is significantly greater than zero were considered to be positively selected by spawners. These classes were grouped together into ranges so that we had a defined range for positive selection for each of the four variables. These ranges were used to define suitable spawning habitat (SSH). A particular point in the river was considered SSH if the four microhabitat variables had values within the ranges considered suitable for spawning and had class 1 embeddedness (loose gravel with little or moderate fine elements; Stuart 1953; Beard \& Carline 1991).

All the values of mean and bottom velocity which were significantly selected at the $95 \%$ level were considered suitable for spawning. We relaxed this criterion for surface substrate size by allowing some disperse stones of other sizes to be present within the SSH. For water depth, as well as the significantly selected values, we also included all values up to the maximum used depth. These depths were included because it seems quite likely that the upper limit for spawning depth arises from the limited availability of greater water depths with appropriate current and from the inability of research workers to detect deep redds (Crisp \& Carling 1989).

Therefore, the SSH satisfies the brown trout requirements for depth, mean water velocity, bottom velocity, substrate size and embeddedness. Because the SSH meets the five requirements, corresponding to the five microhabitat variables, we assumed that SSH represents good-quality spawning habitat. Nevertheless, females may actually spawn in less suitable habitats as well, e.g., in sites that only meet three or four requirements.

Within each section, we identified a single continuous area that satisfied the five microhabitat requirements. This polygon was considered the SSH for brown trout in the section, and its area was then measured. Following Delacoste et al. (1993), only the largest continuous area of SSH within the section was 


\section{Gortázar et al.}

considered, while smaller separate patches were ignored.

\section{Redd superimposition}

Two analyses were performed to investigate whether redd superimposition was caused by a high density of spawners relative to the available spawning habitat or not. First, simple regression analyses were performed to determine whether the percentage of superimposed redds was correlated with redd numbers, SSH or redd density (number of redds divided by $\mathrm{SSH}$ ) in each section. As the actual number of spawners is unknown, redd density was used as a surrogate of spawner density.

Second, following Essington et al. (1998) study, a simulation-based analysis was carried out to compare the observed number of superimposed redds versus the expected if redd sites were randomly distributed within the SSH, given the actual number of redds and their area. In each section, we estimated the expected number of superimposed redds if they were randomly placed within the SSH, assuming that all redds were completely inside the SSH. The redd area used in the simulations was the average area of the nonsuperimposed redds (new redds). Mean redd area was calculated separately for each part of the river, resulting $0.76 \mathrm{~m}^{2}\left(\mathrm{SD}=0.38 \mathrm{~m}^{2}\right)$ for group $\mathrm{A}$ and $0.87 \mathrm{~m}^{2}\left(\mathrm{SD}=0.59 \mathrm{~m}^{2}\right)$ for group B. In the simulations, we considered that one redd was superimposed if it overlapped another by more than $25 \%$ of its area. When several redds were overlapped in a simulation, we considered that only one redd was not superimposed, so the number of superimposed redds was considered to be the number of overlapped redds minus one (the first one constructed). 1000 simulations were performed in each section, and the resulting mean and 0.05 and 0.95 percentiles of the expected number of superimposed redds were calculated. If the observed number of superimposed redds exceeded the 0.95 percentile of the simulated superimposition, we concluded that redd superimposition was significantly higher than that expected if redd sites were randomly selected.

\section{Results}

Both parts of the river Castril provided very different results. In the part of the stream connected to the reservoir (group B), 127 redds were detected, and 71 redds were superimposed over previously constructed redds, yielding a rate of redd superimposition of $55.9 \%$. In the part of the stream that did not have reservoir-migrant trouts (group A), the total redd count was 18 and 6 superimposed redds were detected, a superimposition rate of $33.3 \%$.

\section{Suitable Spawning Habitat (SSH)}

The distributions of available and used microhabitat were markedly different for the four variables: depth (Kolmogorov-Smirnov two-sample test, $D=0.27$, $P<0.05$ ), mean water column velocity (K-S test, $D=0.60, P<0.01$ ), bottom water velocity (K-S test, $D=0.67, P<0.01)$ and surface substrate size $(\mathrm{K}-\mathrm{S}$ test, $D=0.69, P<0.01)$. Female brown trout showed significant positive selection $(P<0.01)$ for depths between 10 and $30 \mathrm{~cm}$, mean velocities between 30 and $60 \mathrm{~cm} \mathrm{~s}^{-1}$, bottom velocities between 15 and $60 \mathrm{~cm} \mathrm{~s}^{-1}$ and substrate sizes ranging $4-30 \mathrm{~mm}$ (Fig. 1).

Although only depths between 10 and $30 \mathrm{~cm}$ were significantly selected by females, values $>30 \mathrm{~cm}$ up to the highest used depth $(50 \mathrm{~cm})$ were considered suitable as well (see Methods for details). Note that the depth class $30-40 \mathrm{~cm}$ was not significantly avoided by
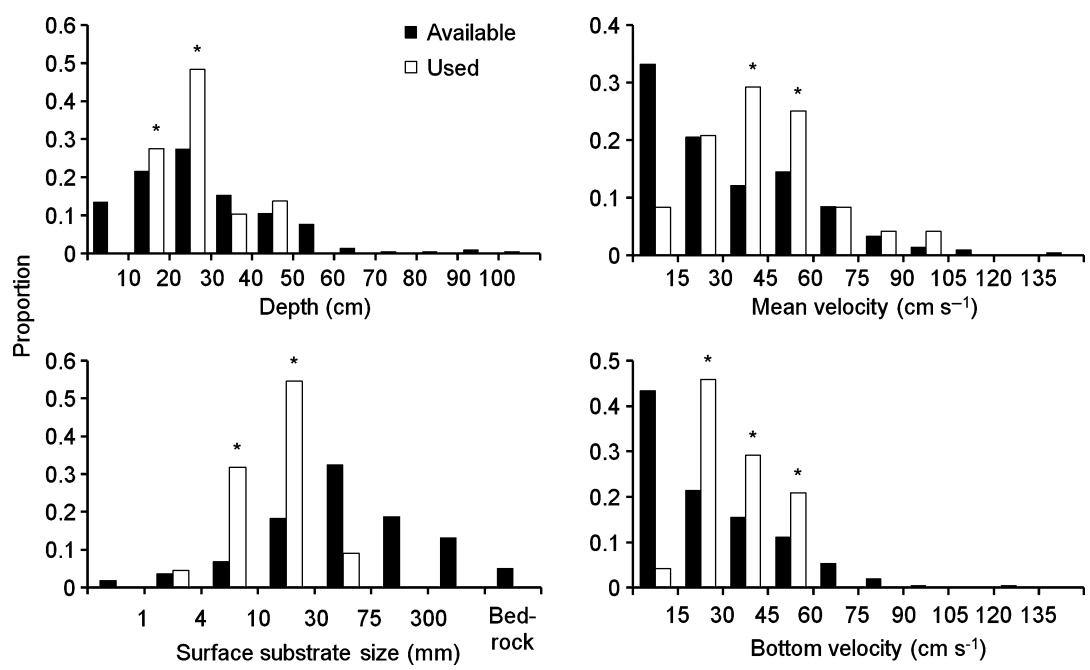

Fig. 1. Distribution of available (solid bars) and used (open bars) values of depth, mean water column velocity, bottom water velocity and substrate size. The asterisk indicates a significant Strauss electivity index $(P<0.01)$. 
Brown trout redd superimposition

Table 1. Observed number of redds and superimposed redds (percentage in brackets) in each section.

\begin{tabular}{|c|c|c|c|c|c|}
\hline Section & $\begin{array}{l}\text { Observed } \\
\text { number } \\
\text { of redds }\end{array}$ & $\begin{array}{l}\text { Observed } \\
\text { superimposedredds }\end{array}$ & Section & $\begin{array}{l}\text { Observed } \\
\text { number } \\
\text { of redds }\end{array}$ & $\begin{array}{l}\text { Observed } \\
\text { superimposed } \\
\text { redds }\end{array}$ \\
\hline 1 & 4 & $1(25)$ & 4 & 10 & $6(60)$ \\
\hline 2 & 4 & $3(75)$ & 5 & 5 & $1(20)$ \\
\hline \multirow[t]{19}{*}{3} & 10 & $2(20)$ & 6 & 10 & $5(50)$ \\
\hline & & & 7 & 5 & $1(20)$ \\
\hline & & & 8 & 2 & $0(0)$ \\
\hline & & & 9 & 3 & $1(33.3)$ \\
\hline & & & 10 & 3 & $2(66.7)$ \\
\hline & & & 11 & 6 & $3(50)$ \\
\hline & & & 12 & 6 & 5 (83.3) \\
\hline & & & 13 & 8 & $5(62.5)$ \\
\hline & & & 14 & 7 & $4(57.1)$ \\
\hline & & & 15 & 4 & $3(75)$ \\
\hline & & & 16 & 2 & $1(50)$ \\
\hline & & & 17 & 7 & $4(57.1)$ \\
\hline & & & 18 & 4 & $1(25)$ \\
\hline & & & 19 & 10 & $8(80)$ \\
\hline & & & 20 & 5 & $3(60)$ \\
\hline & & & 21 & 12 & $7(58.3)$ \\
\hline & & & 22 & 8 & $5(62.5)$ \\
\hline & & & 23 & 7 & $5(71.4)$ \\
\hline & & & 24 & 3 & 1 (33.3) \\
\hline Group A & 18 & $6(33.3)$ & Group B & 127 & $71(55.9)$ \\
\hline
\end{tabular}

females $(P>0.05)$, and in the class $40-50 \mathrm{~cm}$ use exceeded availability.

In summary, every site within the SSH must have depth between 10 and $50 \mathrm{~cm}$, mean water velocity between 30 and $60 \mathrm{~cm} \mathrm{~s}^{-1}$, bottom velocity between 15 and $60 \mathrm{~cm} \mathrm{~s}^{-1}$, surface substrate size in the range 4-30 $\mathrm{mm}$ and embeddedness class 1 . The SSH area measured in each section ranged from 10.5 to $90.8 \mathrm{~m}^{2}$.

\section{Redd superimposition}

Among the studied sections, observed superimposition rates ranged from $0 \%$ in section 8 , where only two redds were constructed and none of them were superimposed, to $83.3 \%$ in section 12 , where five of the six constructed redds were superimposed (Table 1). Overall, the average superimposition rate for the studied sections in the river Castril was $53.1 \%$ (77 superimposed out of 145 redds).

Simple regression analyses showed that the percentage of superimposed redds was not correlated with either redd numbers (regression analysis: $R^{2}=0.103$, $P=0.13, N=24)$ or available SSH area $\left(R^{2}=0.001\right.$, $P=0.9, N=24)$. Moreover, superimposition and redd density (number of redds per SSH area) were also not correlated $\left(R^{2}=0.096, P=0.14, N=24\right.$, Fig. 2). Significance was not improved by analysing group B $\left(R^{2}=0.063, P=0.27, N=21\right)$ or group A alone $\left(R^{2}=0.868, P=0.24, N=3\right)$. Furthermore, the sections with high redd density had high rates of redd superimposition, but the sections with low redd

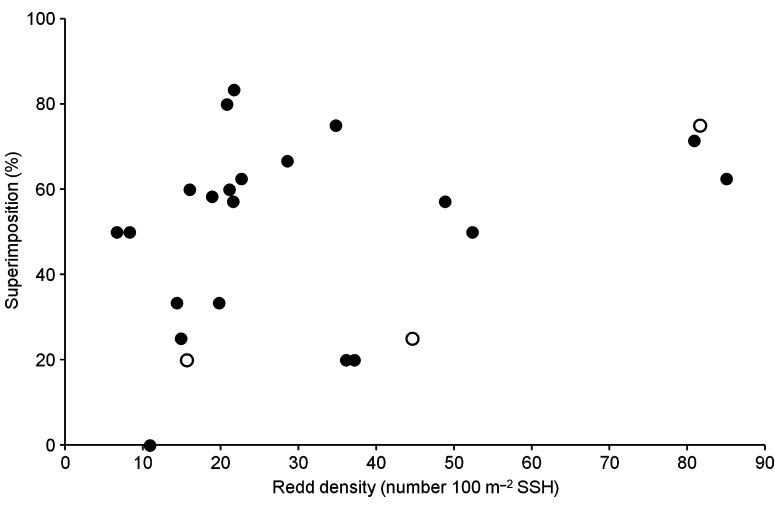

Fig. 2. Relationship between redd superimposition and redd density in 24 sections within group A (open circles) and group B (solid circles).

density showed a highly variable superimposition, ranging from 0 to more than $80 \%$ (Fig. 2).

Almost all the sections (23 of 24) showed a higher rate of redd superimposition than expected if redds were placed randomly (Fig. 3a). The exception was section 8 , which is the only section where no redds were superimposed. In eight sections, the difference between observed and expected superimposition was significant $(P<0.05)$. Furthermore, in another eight sections, the observed number of superimposed redds equalled the 0.95 percentile of the expected random superimposition, thus being right at the limit of the statistical significance $(P=0.05)$.

The rate of redd superimposition was significantly higher than expected if redds were placed randomly 


\section{Gortázar et al.}

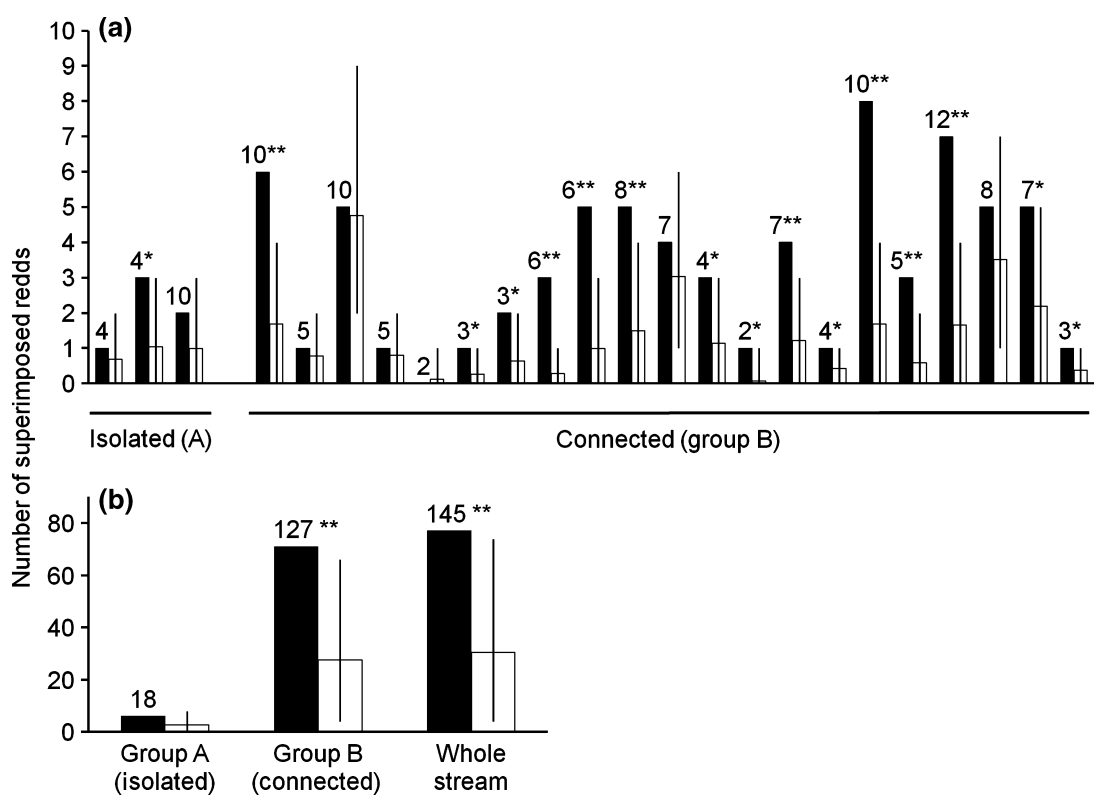

Fig. 3. Observed number of superimposed redds (solid bars) and mean expected superimposition if redds were randomly placed over the suitable spawning habitat (SSH) (open bars). Lines denote 0.05 and 0.95 percentiles of the expected number of superimposed redds, calculated by performing 1,000 simulations of random redd location over the SSH. The total number of observed redds is shown above bars. (a) Results for each section and (b) aggregated results. **Significant difference at the $95 \%$ s.l. $(P<0.05)$ between expected and observed superimposition. $*$ The difference is right at the limit of statistical significance $(P=0.05)$.

both after the aggregation of all the sections of the stream and among the reaches connected to the reservoir (group B). Regarding the part of the stream isolated from the reservoir (group A), redd superimposition was also higher than expected, but without statistical significance at the 95\% s.l. (Fig. 3b).

\section{Discussion}

The rate of redd superimposition in the part of the river Castril connected to the reservoir (group B) was $55.9 \%$, close to the highest values found in the literature: Anderson (1983) observed percentages of superimposed redds higher than 50\%, and Essington et al. (1998) reported that between $18 \%$ and $50 \%$ of brown trout females constructed their redds over preexisting ones. In a sea trout population, Rubin et al. (2004) observed that $60 \%$ of the spawning area was used by at least two different pairs. In the isolated reaches (group A), the superimposition rate was lower $(33.3 \%)$ but non-negligible in comparison with the values from other streams (Anderson 1983; Essington et al. 1998).

\section{Suitable Spawning Habitat (SSH)}

Suitable spawning habitat (SSH) has been defined as the continuous area inside which every point satisfies five requirements, one for each microhabitat variable: depth, mean water column velocity, bottom water velocity, substrate size and embeddedness. We are confident that SSH represents good-quality spawning habitat for brown trout in the river Castril, because it takes into consideration microhabitat characteristics that are positively selected by females in this river.
Furthermore, only one continuous SSH area has been used within each section, while smaller separate patches have not been considered in the analyses (Delacoste et al. 1993).

Several factors illustrate that the criteria used for defining the SSH are demanding. First, it is known that spawning brown trout choose locations with optimum combinations of several microhabitat variables rather than positions with more preferred levels of any single factor (Shirvell \& Dungey 1983). Because of this, we imposed the criterion of satisfying the five microhabitat requirements, and it was not possible to compensate an unsuitable value in one variable by high suitability values in other variables. Second, we decided to use both mean velocity and bottom velocity in the definition of SSH, despite the fact that only the latter has been suggested to have biological significance: females actually sense the bottom velocity when they choose a place to spawn, because it determines the hydraulic conditions around the nest that will act during embryo development (Shirvell \& Dungey 1983; Delacoste et al. 1995). Both water velocities were considered in order to impose demanding criteria for SSH and thus to assure that it represents high-quality spawning habitat. Third, only embeddedness class 1 , which is the most favourable type for redd digging (gravel loose and with little fine elements), has been considered suitable for spawning.

The selection of spawning habitat may exhibit regional and river-specific characteristics (Delacoste et al. 1995). For this reason, we analysed the values of each microhabitat variable that were selected by female brown trout in the river Castril, and we used these particular values to compute the SSH. Anyway, our results on female selection for spawning 
microhabitat characteristics are consistent with previous studies on habitat selection, despite some minor differences (Table 2). Grost et al. (1990) also used the Strauss electivity index to investigate habitat selection and reported narrower significant selection ranges for depth and mean velocity, but the intervals in which habitat use exceeded availability did include the suitable values obtained by us. Grost et al. (1990) did not observe any significant selection for substrate size, although the interval with highest use in relation to its availability was similar to our suitable values for this variable.

The suitable ranges obtained in our study were similar to the majority of the reviewed values from several authors (Table 2). Interestingly, Raleigh et al. (1986) did not report any upper limit for depth, which supports our decision to consider the range $10-50 \mathrm{~cm}$ as suitable. The biggest disparities between our data and the literature were for the bottom velocities given by Delacoste et al. (1995) and Mayo et al. (1995). However, these authors reported rather lower velocities than those used for spawning in several studies (Shirvell \& Dungey 1983; Plasseraud et al. 1990; Sorensen et al. 1995). Thus, we are confident that the ranges we used as suitable to compute the SSH were correct and represented high-quality spawning habitat in the river Castril.

\section{Spawning habitat influence on redd superimposition}

Several authors have supported that redd superimposition in salmonids is caused by high density of spawners, i.e., an excess of reproductive females and/or a scarcity of suitable habitat (Champigneulle et al. 1988, 2003; Beard \& Carline 1991; Rubin et al. 2004). If redd superimposition was caused by habitat availability alone (limited suitable habitat or excess of spawners), a positive correlation between superimposition rate and redd density would be expected. We did not find any significant relationship between these variables in Castril. Our simple regression analysis showed high superimposition rates at high redd densities, but at lower redd densities, superimposition was highly variable (Fig. 2).

Obviously, if the number of spawners is too high in relation to available spawning habitat, superimposition will often occur, because there is no more space for reproduction. Thus, a minimum superimposition rate can be determined by redd density in the form of a linear function. In this sense, a given density may impose a superimposition rate over which female spawners can increase the rate but not decrease it. So, if the density of spawners is low (and thus spawning habitat is not limiting), a high degree of superimposition suggests that the availability of spawning habitat is not the sole cause of superimposition. For instance, in many sections of the river Castril, we observed low redd density and high superimposition rates.

Moreover, the results of the simulation-based analysis showed that, in the majority of cases, the observed superimposition is higher than that expected if redd sites were randomly placed over the SSH. This fact strongly suggests that females choose specific sites for redd construction instead of randomly dispersing over the available quality habitat. The difference between observed and expected superimposition is less clear in the isolated reaches (group A) than in the part of the river connected to the reservoir (group B), but it is not

Table 2. Brown trout selection for spawning microhabitat in several studies. Two criteria are shown, one more demanding and another more relaxed. Notes in the references relate to methodology explanations.

\begin{tabular}{|c|c|c|c|c|c|}
\hline Reference & Criterion & Depth $(\mathrm{cm})$ & $\begin{array}{l}\text { Mean velocity } \\
\left(\mathrm{cm} \mathrm{s}^{-1}\right)\end{array}$ & $\begin{array}{l}\text { Bottom velocity } \\
\left(\mathrm{cm} \mathrm{s}^{-1}\right)\end{array}$ & $\begin{array}{l}\text { Substrate } \\
\text { size }(\mathrm{mm})\end{array}$ \\
\hline This study & & $10-30$ & $30-60$ & $15-60$ & $4-30$ \\
\hline \multirow[t]{2}{*}{ Grost et al. $1990 \dagger$} & Selection & $12.3-18.3$ & $24.5-36.6$ & & No \\
\hline & Use > av. & $12.3-30.5$ & $24.5-73.2$ & & $7-75(7-25) \ddagger$ \\
\hline \multirow[t]{2}{*}{ Bovee $1978 \S$} & $\mathrm{PU}>0.9$ & $15-25$ & $45-65$ & & $2-20$ ศ \\
\hline & $\mathrm{PU}>0.5$ & $10-35$ & $30-75$ & & \\
\hline \multirow[t]{2}{*}{ Raleigh et al. $1986+\dagger$} & $\mathrm{SI}=1$ & $>25$ & & $20-50$ & $6-76$ \\
\hline & $\mathrm{SI}>0.5$ & $>15$ & & $15-85$ & $4-80$ \\
\hline \multirow[t]{2}{*}{ Delacoste et al. $1995+t$} & $\mathrm{HI}>0.9$ & $15-25$ & & $25-30$ & $2-100$ \\
\hline & $\mathrm{HI}>0.5$ & $10-30$ & & $15-35$ & \\
\hline \multirow[t]{2}{*}{ Mayo et al. $1995 \S$} & $\mathrm{PU}>0.9$ & $15-28$ & $20-35$ & $12-25$ & $10-30$ ศ \\
\hline & $\mathrm{PU}>0.5$ & $8-42$ & $13-50$ & $5-37$ & \\
\hline
\end{tabular}

†Comparison between available and used habitat by means of the Strauss electivity index: use > av.: habitat used in a greater proportion than its availability; selection: significant selection at the $95 \%$ s.l.

\#For the substrate range 7-75 mm, use exceeded availability. The difference was most marked in the range 7-25 mm.

$\S \mathrm{PU}$, probability of use, ranges from 0 to 1 .

$\top \mathrm{PU}=1$.

$\uparrow$ Category one curves (based on literature or professional opinion), SI, suitability index.

$\$$ HI, habitat suitability, ranges from 0 (not suitable) to 1 (optimal). 


\section{Gortázar et al.}

possible to draw any conclusions from this, because we only had data from three sections within group A. However, even in group A, the observed superimposition was higher than would be expected by chance. Nevertheless, superimposition rate was lower in group A than in group B, and this may be related to differences in spawning behaviour or female body size: it is known that spawners from group B are larger than those from group A owing to the presence of reservoir-migrant trout (Gortázar et al. 2007), but again, the lack of data from group A prevents us from drawing any conclusions about this issue.

At this point, it is convenient to make an observation about two methodological factors related to the simulation-based analysis, which reduced the probability of achieving our result that the observed superimposition was greater than the expected. These factors act by underestimating the observed superimposition or by overestimating the simulated superimposition: (i) during fieldwork, every time it was not clear whether an individual redd had been superimposed or not, we considered that no superimposition had occurred, and this may underestimate the observed superimposition. (ii) Furthermore, when several redds were overlapped in a simulation, we considered that all the redds except one (the first one constructed) were superimposed. This may overestimate the simulated superimposition, because it is possible that not one but two or more redds were first built without superimposition and later a single redd overlapped several of the previous redds.

We believe that the most likely explanation for the high superimposition rates, even at low spawner density, is that brown trout females have some kind of preference to spawn over pre-existing redd sites, as showed by Essington et al. (1998) in a behavioural experiment. These authors argued that the presence of an existing redd makes a particular site more attractive for spawning than it would otherwise be, because the female may reduce the energetic cost of reproduction and increase subsequent fitness. Youngson et al. (2011) confirmed the finding that females tend to spawn close to locations that have already been used. Therefore, the modification of stream substratum by prior spawners must be regarded as a factor that affects spawning site selection in brown trout.

It is important to underline that our findings refer to the microhabitat scale at which this study has been conducted: Females may exhibit a preference to spawn over a previously used redd site, but this only occurs after the choice of a particular reach within the accessible part of the stream and once the female has decided on a particular streambed patch within the reach. These decisions are largely determined by the suitability and availability of spawning habitat (e.g.,
Shirvell \& Dungey 1983; Beard \& Carline 1991; Delacoste et al. 1993).

Regarding the outcome of redd superimposition, several authors have supported the idea that it may negatively impact spawning success in salmonid populations by damaging the previously laid eggs or fry (Hayes 1987; Rubin \& Glimsäter 1996; Taniguchi et al. 2000). However, Anderson (1983) observed that the contents of pre-existing redds are not necessarily destroyed when superimposition occurs. Weeber et al. (2010) found that redd superimposition did not affect bull trout (Salvelinus confluentus Suckley) egg-to-fry survival owing to the shallower scouring by the following kokanee (Oncorhynchus nerka Walbaum) spawners. In the river Castril, Gortázar et al. (2007) suggested that the timing of brown trout spawning, which extends from December to April, may reduce the potential damage of redd superimposition: Smaller females seem to spawn later in the season, thus avoiding having their nests destroyed by larger females, which are known to bury their eggs deeper (van den Berghe \& Gross 1984, 1989). In this way, redds of larger females would be less susceptible to damage from the superimposition of smaller spawners which bury their eggs shallower.

Furthermore, in limestone streams such as the Castril, the chemical process of calcium carbonate precipitation can potentially embed the gravel, making it cohesive and difficult to excavate. It seems plausible that the advantage of reusing a redd site would be greater in rivers with this type of substrate, where the gravel was very cohesive and thus the substrate was highly embedded in unused sites. It would be valuable to address this hypothesis by the development of a comparative study between rivers with different degrees of substrate embeddedness, to analyse whether the superimposition preference is higher in streams with more embedded substrate or not. More research is also needed to fill the critical lack of data on the ecology of the southernmost brown trout populations, to manage them better.

\section{Acknowledgements}

This study was partially funded by a postgraduate grant awarded to J. Gortázar by the Polytechnic University of Madrid. We would like to thank José María Montoro (Director of the Sierra de Castril Natural Park) and the Regional Government of Andalusia for allowing us to survey the river Castril. We would also like to thank the Natural Park guards for sharing their experience and knowledge of the river with us. Many thanks to the company Ecohidráulica S.L. (http:// www.ecohidraulica.com) for sharing their equipment and expertise with us. Last but not least, thanks to David Flórez and Hélène Arambourou who were of invaluable assistance throughout the fieldwork. 


\section{Brown trout redd superimposition}

\section{References}

Almodóvar, A. 2007. Análisis de la variabilidad genética de la trucha común en Andalucía. Departamento de Zoología y Antropología Física, Facultad de Biología, Universidad Complutense de Madrid. 139 pp.

Anderson, D.W. 1983. Factors affecting brown trout reproduction in southeastern Minnesota streams. Minnesota: Department of Natural Resources, Section of Fisheries, Investigational Report 376.37 pp.

Baxter, C.V. \& Hauer, F.R. 2000. Geomorphology, hyporheic exchange, and selection of spawning habitat by bull trout (Salvelinus confluentus). Canadian Journal of Fisheries and Aquatic Sciences 57: 1470-1481.

Baxter, J.S. \& McPhail, J.D. 1999. The influence of redd site selection, groundwater upwelling, and over-winter incubation temperature on survival of bull trout (Salvelinus confluentus) from egg to alevin. Canadian Journal of Zoology 77: 12331239.

Beard Jr, T.D. \& Carline, R.F. 1991. Influence of spawning and other stream habitat features on spatial variability of wild brown trout. Transactions of the American Fisheries Society 120: 711-722.

van den Berghe, E.P. \& Gross, M.R. 1984. Female size and nest depth in coho salmon (Oncorhynchus kisutch). Canadian Journal of Fisheries and Aquatic Sciences 41: 204206.

van den Berghe, E.P. \& Gross, M.R. 1989. Natural selection resulting from female breeding competition in a Pacific salmon (coho: Oncorhynchus kisutch). Evolution 43: 125-140.

Bovee, K.D.. 1978. Probability-of-use criteria for the family Salmonidae. Instream Information Paper No. 4. U.S. Fish and Wildlife Service. 80 pp.

Champigneulle, A., Mélhaoui, M., Maisse, G., Baglinière, J.L., Gillet, C. \& Gerdeaux, D. 1988. Premières observations sur la truite (Salmo trutta L.) dans le Redon, un petit affluentfrayère du lac Léman. Bulletin Français de la Pêche et de la Pisciculture 310: 59-76.

Champigneulle, A., Largiader, C.R. \& Caudron, A. 2003. Reproduction de la truite (Salmo trutta L.) dans le torrent de Chevenne, Haute-Savoie. Un fonctionnement original? Bulletin Français de la Pêche et de la Pisciculture 369: 41-70.

Crisp, D.T. \& Carling, P.A. 1989. Observations on siting, dimensions and structure of salmonid redds. Journal of Fish Biology 34: 119-134.

Curry, A.R. \& Noakes, D.L.G. 1995. Groundwater and the selection of spawning sites by brook trout (Salvelinus fontinalis). Canadian Journal of Fisheries and Aquatic Sciences 52: 1733-1740.

Delacoste, M., Baran, P., Dauba, F. \& Belaud, A. 1993. Étude du macrohabitat de reproduction de la truite commune (Salmo trutta L.) dans une rivière pyrénéenne, la Neste du Louron. Évaluation d'un potentiel de l'habitat physique de reproduction. Bulletin Français de la Pêche et de la Pisciculture 331: 341-356.

Delacoste, M., Baran, P., Lascaux, J.M., Segura, G. \& Belaud, A. 1995. Capacité de la méthode des microhabitats a prédire l'habitat de reproduction de la truite commune. Bulletin Français de la Pêche et de la Pisciculture 337/338/339: 345353.
Elliott, J.M. 1994. Quantitative ecology and the brown trout. New York: Oxford University Press, 286 pp.

Essington, T.E., Sorensen, P.W. \& Paron, D.G. 1998. High rate of redd superimposition by brook trout (Salvelinus fontinalis) and brown trout (Salmo trutta) in a Minnesota stream cannot be explained by habitat availability alone. Canadian Journal of Fisheries and Aquatic Sciences 55: 2310-2316.

Garrett, J.W., Bennett, D.H., Frost, F.O. \& Thurow, R.F. 1998. Enhanced incubation success for kokanee spawning in groundwater upwelling sites in a small Idaho stream. North American Journal of Fisheries Management 18: 925-930.

Gortázar, J., García de Jalón, D., Alonso-González, C., Vizcaíno, P., Baeza, D. \& Marchamalo, M. 2007. Spawning period of a southern brown trout population in a highly unpredictable stream. Ecology of Freshwater Fish 16: 515527.

Grost, R.T., Hubert, W.A. \& Wesche, T.A. 1990. Redd site selection by brown trout in Douglas Creek, Wyoming. Journal of Freshwater Ecology 5: 365-371.

Grost, R.T., Hubert, W.A. \& Wesche, T.A. 1991. Description of brown trout redds in a mountain stream. Transactions of the American Fisheries Society 120: 582-588.

Hayes, J.W. 1987. Competition for spawning space between brown (Salmo trutta) and rainbow trout (S. gairdneri) in a lake inlet tributary, New Zealand. Canadian Journal of Fisheries and Aquatic Sciences 44: 40-47.

Landergren, P. 1999. Spawning of anadromous rainbow trout, Oncorhynchus mykiss (Walbaum): a threat to sea trout, Salmo trutta L., populations ? Fisheries Research 40: 55-63.

Mayo, M., Gallego, B., García de Jalón, D. \& Brotóns, P.A. 1995. Preferencias de hábitat de la trucha común en la época de freza. Río Dulce, Guadalajara. Limnetica 11: 49-54.

Plasseraud, O., Lim, P. \& Belaud, A. 1990. Observations préliminaires sur le fonctionnement des zones de frayères de la truite commune (Salmo trutta fario) dans deux cours d'eau ariégois (le Salat et l'Alet). Bulletin Français de la Pêche et de la Pisciculture 318: 72-81.

Raleigh, R.F., Zuckerman, L.D. \& Nelson, P.C.. 1986. Habitat suitability index models and instream flow suitability curves: brown trout. Biological Report 82. U.S. Fish and Wildlife Service. 65 pp.

Rubin, J.-F. \& Glimsäter, C. 1996. Egg-to-fry survival of the sea trout in some streams of Gotland. Journal of Fish Biology 48: 585-606.

Rubin, J.-F., Glimsäter, C. \& Jarvi, T. 2004. Characteristics and rehabilitation of the spawning habitats of the sea trout, Salmo trutta, in Gotland (Sweden). Fisheries Management and Ecology 11: 15-22.

Shirvell, C.S. \& Dungey, R.G. 1983. Microhabitats chosen by brown trout for feeding and spawning in rivers. Transactions of the American Fisheries Society 112: 355-367.

Sorensen, P.W., Cardwell, J.R., Essington, T. \& Weigel, D.E. 1995. Reproductive interactions between sympatric brook and brown trout in a small Minnesota stream. Canadian Journal of Fisheries and Aquatic Sciences 52: 1958-1965.

Strauss, R.E. 1979. Reliability estimates for Ivlev's electivity index, the forage ratio, and a proposed linear index of food selection. Transactions of the American Fisheries Society 108: 344-352. 


\section{Gortázar et al.}

Stuart, T.A. 1953. Water currents through permeable gravels and their significance to spawning salmonids. Nature 172: 407-408.

Taggart, J.B., McLaren, I.S., Hay, D.W., Webb, J.H. \& Youngson, A.F. 2001. Spawning success in Atlantic salmon (Salmo salar L.): a long-term DNA profiling-based study conducted in a natural stream. Molecular Ecology 10: 10471060 .

Taniguchi, Y., Miyake, Y., Saito, T., Urabe, H. \& Nakano, S. 2000. Redd superimposition by introduced rainbow trout, Oncorhynchus mykiss, on native charrs in a Japanese stream. Ichthyological Research 47: 149-156.

Weeber, M.A., Giannico, G.R. \& Jacobs, S.E. 2010. Effects of redd superimposition by introduced kokanee on the spawning success of native bull trout. North American Journal of Fisheries Management 30: 47-54.

Witzel, L.D. \& MacCrimmon, H.R. 1983. Redd-site selection by brook trout and brown trout in southwestern Ontario streams. Transactions of the American Fisheries Society 112: 760-771.

Youngson, A.F., Piertney, S.B., Thorley, J.L., Malcolm, I.A. \& Soulsby, C. 2011. Spatial association of nest construction by brown trout Salmo trutta. Journal of Fish Biology 78: 713725.

Zar, J.H. 1999. Biostatistical Analysis, 4th edn. Upper Saddle River, New Jersey: Prentice Hall International. 564 pp. 